\begin{tabular}{|l|l|l||}
\hline \multicolumn{2}{|c|}{ PublisherInfo } \\
\hline \hline PublisherName & $:$ & BioMed Central \\
\hline \hline PublisherLocation & $:$ & London \\
\hline \hline PublisherImprintName & $:$ & BioMed Central \\
\hline \hline
\end{tabular}

\title{
Old flies oxidize
}

\begin{tabular}{||l|l|l||}
\hline \multicolumn{2}{|c||}{ ArticleInfo } \\
\hline \hline ArticleID & $:$ & 3851 \\
\hline \hline ArticleDOI & $:$ & $10.1186 /$ gb-spotlight-20001205-01 \\
\hline \hline ArticleCitationID & $:$ & spotlight-20001205-01 \\
\hline \hline ArticleSequenceNumber & $:$ & 288 \\
\hline \hline ArticleCategory & $:$ & Research news \\
\hline \hline ArticleFirstPage & $:$ & 1 \\
\hline \hline ArticleLastPage & $:$ & 2 \\
\hline \hline & $:$ & RegistrationDate : 2000-12-05 \\
ArticleHistory & $:$ & OnlineDate $: 2000-12-05$ \\
\hline \hline ArticleCopyright & $:$ & BioMed Central Ltd2000 \\
\hline \hline ArticleGrants & $:$ & \\
\hline \hline ArticleContext & $:$ & 130591111 \\
\hline \hline
\end{tabular}


William Wells

Email: wells@biotext.com

In the December 5 Proceedings of the National Academy of Sciences, Zou et al. find that only some of the processes of aging in the fly can be explained by increased oxidative stress (Proc Natl Acad Sci USA 2000, 97:13726-13731). Zou et al. analyze expression profiles of both aging flies and young flies exposed to the free-radical generator paraquat, using microarrays of approximately 8000 expressed sequence tags (ESTs) that cover 30-40\% of the Drosophila genome. Of these ESTs, 43 are upregulated with age, and 89 are downregulated. There are reductions in transcripts involved in reproduction, metabolism and protein turnover. Some genes encoding detoxification agents and chaperones are upregulated, while others are downregulated. Many of these changes are similar to those seen in the mouse, although the specific genes involved tend to differ. One third of all age-regulated genes show significant changes in response to oxidative stress. This suggests that free radicals are not the only causal factor in aging.

\section{References}

1. Proceedings of the National Academy of Sciences, [http://www.pnas.org/]

2. Molecular biology of aging.

3. Gene expression profile of aging and its retardation by caloric restriction.

This PDF file was created after publication. 